\title{
243. シスプラチン耐性細胞に対するプラチナ化合物の検討
}

\author{
立川拓也 - 熊沢博文・堀 芳朗・和田安弘 - 山崎典子 - 山下敏夫 - 熊沢忠躬（関西医大） \\ 河本圭司（同 脳神経外科）
}

頭䫮部領域に扔いてもシスプラチン(CDDP) の出現 以来化学憭法は格段に進歩してきた。哖前は手術不能 であった進行澏に対しても化学察法を施行することで 手術可能七まてになってきている。しかし一方では腫 湟細胞の耐性化も問題となってきており化学療法を行 う上で大きな妨げとなってきている。一つの薬剤に対 して耐性を示した細胞は他の薬剤に対してもしばしば 耐性在認中ることも知られている。そこで今回我々は 当科で樹立Lた CDDP 耐性 KB 細胞（KBrc 細胞）を 用いて CDDP 以外の薬剂に対しての感受性の检討を $\mathrm{KB}$ 細咆上の比較で行った。亦た而性の機序解明の目 的で細胞内のブラチナ (Pt) 濃度の測定を行った。
結果 CDDPを含むPt製用江対しては 2 倍から 250倍の感受性の差が認められた。しかし $5 \mathrm{FU}, \mathrm{Pe}$ plomysinに対しては 2 細胞間に扔いて薬郕の感受性 に差が認めら机なかった。また細胞内Pt濃度の測定 において, $\mathrm{KBrc}$ 細胞に比較して $47 \%$ \% 8 \% と Pt $の$ 集 積の低下が認められた。

まとめ (1) $\mathrm{KBrc}$ 細胞はPt 系の薬剤に対して, KB 細胞との比較において感受性に差が認められた。しか し, 5FU, Peplomysinに対しては 2 細胞間に扔いて感 受性に差が認められなかった。 (2) KBrc 細胞の耐性の 機序の一つとして細胞内の薬郕 $(\mathrm{Pt})$ の集積の低下が 示唆された。

\section{4. 頭頸部進行癌症例に対する放射線療法と}

\section{カルボプラチン同時併用の試み}

\author{
藤升正人川崎和子・神崎 仁（慶大）
}

目的頭頸部癌に対す万放射線療法上化学療法の同 時伴用は，上门高いCR 率と生存期間の延長を目指し 一，様々な治療が行扎ている。その中でも，シスプ ラチンと照射门阱用は高いCR率で注目されててい。 キニー、シスプラチン誘真体であるカルボフラチンは 腎毒性，要心嘔吐が少なく，外来投与も可能であるこ 上から，放射線療法との併用が容易であると考方られ たたか, 今回頭頸部進行癌で手術不能例，末たは拒否 例に対する放射線療法と力ルボブラチンの併用を試み こその效果と副作用について蚞討した。

方法対象は, 上咽頭 3 例, 中咽頭 2 例, 上顎 2 例, 舌 2 例, 耳下腺 1 例, 喉頭 2 例, 合計 12 例である. Linac 照射老 1 回 2Gy 週 5 回, 計 $40-60 \mathrm{~Gy}$ 施行L, 照射開 始日かり週に1回，照射終了時まで計4 ない７回， カルホフラチン $75 \mathrm{mg} / \mathrm{m}^{2}$ を照射直䏫に2 時間で点滴 投与した。

結果 i) CR 7 例, PR 3 例, NC 2 例, 秦效率83 o 0 , CR 萃58\%てあった。

声癌す1例には術前照射，手術得の再発であったが $\mathrm{CR}$ 示した。また扁桃腫偒り頸部転移に対して照射 上力ルナフラチン併用後頸部郭清術を施行し組織効果

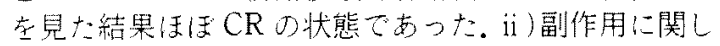
こは，BUNの軽度上昇が2例(17\%) に認め的た。

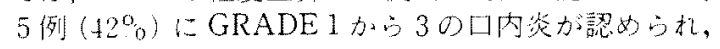

そのうち1例で照射を中断したが1週間後に再開でき た. 白血球減少, 血小板減少, 冥血等は認心られなか った。軽度悪心索訴えた症例が 3 例，嘔吐をみた例は なか力た。

結論放射線療法とカルボプラチンの同時併用は根 治的照射の難しい頭頸部進行癌に対して優れた奏効率 在示した。また强い組織効果别照射後に対しても効果 奎したことから，放射線潦法と力ルボブラチンとの 相垂効果が推察された。副作用で纯口内炎が見られた が照射単独に比バて特に著しいとの印象はなかった。 以上のように，効果および副作用の面から，放射線療 法とカルボプラチンの併用は有効であり，さらに多く

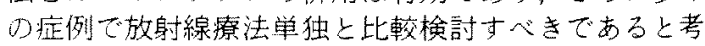
点られた。買問 熊澤博文(暻立宮古)，1）静注 している時間。2) 放射線中での投与の有無. 3) 力 ルボプラチンを $75 \mathrm{mg} / \mathrm{m}^{2}$ て使用した理由. 応答 カルボナラチンと照射の投与順序以関しては今後梌討 すべき問題である。投与童は通常の投与立 $(400 \mathrm{mg} /$ $\mathrm{M}^{2} / 4 \mathrm{wk}$ )では血小板低下が問題となるので今回は少 至投与で㛟尌した。追加大山征夫(北大)。我名

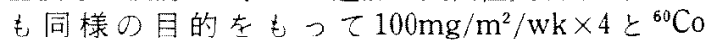
40Gy/4wk 回併用を行っている. 現代, 約30例に行っ たが，全身局所の毒性も tolerableで，効果も期待でき るとの印象学得ている。 